\title{
Architectural Design Using the Enterprise Information System Architecture Planning (EAP) Library and Archive Department of Salatiga City
}

\author{
Fayren G. E. Lodo Ratu \\ Information Technology, Kristen Satya Wacana \\ University, Salatiga, 50771, Indonesia \\ 682019703@student.uksw.edu
}

\author{
Melkior N. N. Sitokdana* \\ Information Technology, Kristen Satya Wacana \\ University, Salatiga, 50771, Indonesia \\ melkior.sitokdana@uksw.edu \\ *Corresponding author
}

\begin{abstract}
The increasingly rapid rate of development of information technology's impact on human life. Both in favor of the activities of individuals or an organization. Organizations must now be able to use Information System in support of the overall business process and can become an overloaded organization in today's business competition. The research looked at the needs of the organization and the constraints that impede business processes at the Department of Libraries and Archives Salatiga. Therefore, in this study researchers used a method of Enterprise Architecture Planning (EAP), which is the stage of planning quality data and pivot on business needs and also how the implementation of the architecture that will do efforts to vision, mission, and goals of the organization. The results of this study provide a blueprint picture related to technology, namely data architecture, application architecture, technology architecture, the implementation plan is a guideline need of Information System at the Department of Libraries and Archives.
\end{abstract}

Keywords-Information System, Enterprise Architecture, EAP, Blueprint, Library.

\section{INTRODUCTION}

The rapid flow of information technology is now highly expected that companies or organizations can have the awareness to adapt to Information System. The existence of an information system is expected to be a solution for organizations or companies to improve their performance. Competition is increasingly evident in various aspects requiring control of information system. Now every field takes the role of information technology to process important data of an organization. Certainly, expected an information system able to create an organization or company achieve its vision, mission, and objectives. The role of information technology cannot be separated from the development and empowerment of an organization. But sometimes an organization that seeks to build information technology without proper planning resulting in the development and implementation done partially. It is sometimes a difficult process of integration of application systems, data, and technology. As happened at the Department of Libraries and Archives Salatiga. Therefore, it needs to be good planning, especially integrate applications across organizational units.

From the observations found some applications used are Slims 7 for librarians and OPAC for visitors. In addition to these applications need to be developed various applications that are more effective and efficient, e.g. mobile applications to serve customers, and also to support the organization's business processes. Based on the above reasons, the researchers used the EAP method that is one of the few methods of enterprise architecture based on the Zachman Framework. EAP is a method used to build information architecture. Generally, EAP is a planning method that pivots on the data quality business requirements and implementation stages of the architecture are done in an effort to make improvements to the business and achieve the mission of the organization. The point EAP is not designing for business and architecture, EAP just makes business requirement definition and architecture.

architecture planning at the Department of Libraries and Archives Salatiga so as to improve service to internal and external parties. EAP will produce a blueprint picture related to information technology, namely data architecture, application architecture, technology architecture, implementation plan which would serve as guidelines for the needs of the Information System at the Department of Libraries and Archives Salatiga. The strategic plan should support the achievement of the vision, mission, goals, and aligned with the business strategy of the Department of Library and Archives of Salatiga in order to create change towards a better future.

and benchmark. The study entitled "Strategic Planning Information System Using Enterprise Architecture Planning at PT. Buana Cipta Karya Sentosa Maumere" performed by Salahudin Robo, Trisno Trisno, Sunardi Sunardi, Santosa Santosa in 2018. In this research, the method used is Enterprise Architecture Planning (EAP). The advantage of using the EAP method is the strategic use of technology to manage data as an asset of the organization and can be run on an assessment of the impact of business change. The results of this research to improve the alignment of business and information technology in the enterprise 
The study entitled "Utilization of Enterprise Architecture Planning in Nursing Harum Jakarta" was conducted by Johan Bastari in 2013. The background of this research aims to build enterprise architecture so that activities can be integrated information system development at Nursing Harum Jakarta. In order to provide the data and information that have good quality to business needs and to provide guidance for the development of applications or information system for the future development of the organization. The result of this case study is a model of the company, catalogs information resources documentation, data architecture, application architecture, technology architecture, and implementation plan. The results also provide a foundation for addressing separately from legacy systems, data integration, and the lack of support of information system for business functions.

The study entitled "Development of an Enterprise Architecture Model Using Information System EAP on Higher Education (Case Study at the University of Bengkulu Dehasen)" performed by Reno Supardi in 2016. The blueprint can help a college in the planning of a good information system. This study has the objective to provide an explanation and understanding of the concept of information management, enterprise architecture, information management function relations, and information architecture that is a component of Enterprise Architecture Planning (EAP). The purpose of this research is to make an enterprise architecture that can support policy strategies in planning the development of information system. This research resulted in information system architecture that is able to offer great progress in aligning and combining information resources, information system and information processes with business strategy.

From previous research, the difference of the research conducted by the authors using Enterprise Architecture Planning (EAP), which is one of the few enterprise architecture methodologies based on the Zachman Framework. EAP is a method used to build an information architecture at the Department of Library and Archives of Salatiga in order to improve service to internal and external parties. EAP will produce a blueprint picture related to information technology, namely data architecture, application architecture, technology architecture, the implementation plan will be a guide to the needs of the Information System at the Department of Libraries and Archives Salatiga.

\section{LITERATURE REVIEW}

Scope of the problem in this research are:

1. Department of Libraries and Archives Salatiga trying to build an information technology without proper planning resulting in the development and implementation done partially. It is sometimes difficult to process the integration of application systems, data, and technology. It is necessary to be good planning, especially integrate applications across organizational units. Good planning can support business processes and achieve the vision and mission of an organization.

2. Limitations of this study are focused on enterprise architecture plan using EAP methods at the Department of Library and Archival Salatiga.

3. Plan of the results obtained in this study that the EAP will be able to provide an overview blueprint on information technology, namely data architecture, application architecture, technology architecture, implementation plan which would serve as guidelines for the needs of the Information System at the Department of Library and Archival Salatiga.

\section{RESEARCH METHODS}

In this section presents the materials, methods, and research stages:

\section{A. Information System}

The information system is a collection of data organized with instructions for their use. An information system can be said to be successful if in accordance with the main purpose of the establishment of the information system. Then the structure of an information system and how to use it depending on the needs or demands to be met. The data collected was obtained from various sources that are within the scope of the system itself.

B. Strategic Planning Information System

Information systems strategic planning is an identification stage application portfolio of the computerbased information systems to support the organization in implementing the business plan and also realize its business objectives. To make the necessary information systems strategic planning study the effect of information systems on business performance and contribution to the organization in selecting strategic steps. In strategic planning of information systems also describes the various tools, techniques, and frameworks for management to align information systems strategy with business strategy, even looking for new opportunities through the application of innovative technologies.

C. Enterprise Architecture Planning (EAP)

Enterprise Architecture Planning (EAP) is the process of defining the architecture in the use of information to support the business and plans to implement the architecture (Kustiyahningsih, 2007). This definition contains three keywords (Kustiyahningsih, 2007). Defining here means doing defining architecture and information system instead of designing the system. Enterprise architecture defines the architecture, and the design of the system is the responsibility of the designer. Architecture, referring to the three architectures defined, namely: data architecture, application architecture, and technology architecture. While the architectural plan, defining what is needed and when to implement.

There are seven main components in EAP that show the steps or stages to determine and plan the implementation of information system architecture. Seven major components are grouped into four layers (Spewak, 1992). 


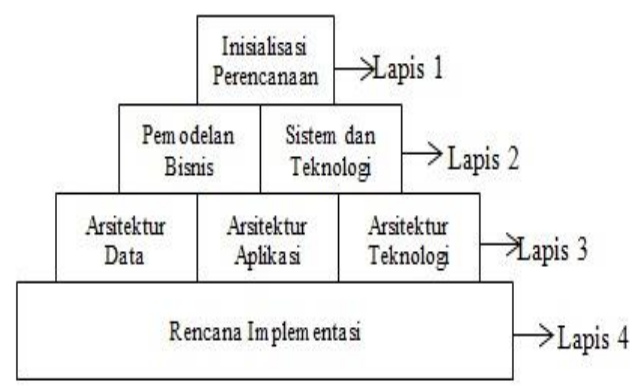

Picture 1. Seven Components and Four Layers in EAP

There are four layers in the EAP, which consists of:

1. Initialization of planning, an initial stage in order to design an architectural model can be directed and run well. In the early stages also made an important base for the processes in the next stage. This stage must be taken seriously, because this stage contains a definition of the scope, work plan/plan of action, choose the method to be used, determine the resources and tools to be used.

2. Conditions Overview At present, divided into 2 parts, namely: Modeling is currently making business-related basic science and information that will be used in conducting business activities and also aims to define the architecture and implementation plan. While the Systems and Technology aims to make the identification and documentation of system applications and enterprise technology platforms used to support the business functions at this time because the enterprise has been running generally has systems and technology for the information system applications.

3. Overview Enterprise Plan for the Future, has 3 parts, namely: Data Architecture which is manufacturing the main data type definitions required to support business activities. The application architecture aims for the manufacture of any application definition that would manage data and provide information to the management of the business functions. Architecture technology is the creation of the technology platform definition needed to provide an environment for applications that will manage the data and support the business functions.

4. The implementation plan is the stage that has the purpose to develop and prepare recommendations implementation plan based on an architecture that has been created.

This study used a qualitative approach for this study based on the presentation of informative knowledge. The method of qualitative research is a research method that is based on the philosophy of positivism, is used to examine the condition of the object that is natural, (as his opponent is an experiment) where researchers are a key instrument, the sampling data source is purposive and snowball, collection techniques by triangulation, analysis data is inductive/qualitative and qualitative research results more pressure on meaning rather than generalizations (Sugiyono, 2010)

\section{Data Collection Technique}

Qualitative research is research that describes and analyzes the phenomena, events, social activities, attitudes, beliefs, perceptions, and people individually or in groups. Sukmadinata (2009), states that the descriptive study aimed at defining a situation or phenomenon as it is (Sukmadinata 2009). Based on the explanation above it can be concluded that this type of research uses qualitative research because the data analysis in the form of words written or oral, and consider the opinions of other people who could be called by the speaker.

In this study consists of several stages that can be described as follows:

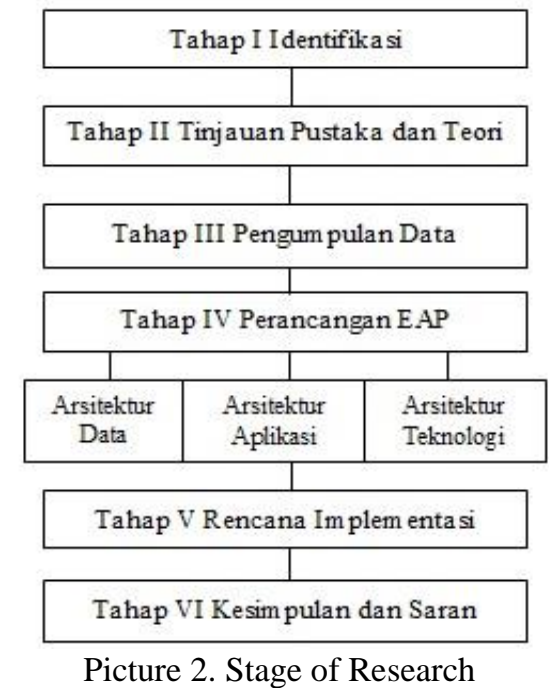

Identification phase I aims to identify the problems that occur in the case studies and also to mark a boundary problem to be studied.

Phase II review of literature and theory was conducted to search for previous research and theoretical basis related to the topics to be researchers use as the basis for the discussion of various EAP methods.

Phase III data collection can be dropped directly into a case study. Observations made during the three months, when the researcher doing practical work in the Department of Library and Archives Salatiga. Researchers used the interview as a means of data collection. Data collected by interviewing Department of Libraries and Archives Development Section Head Salatiga Rinaldi Anggoro Shakti, S.Sos.

Data Architecture: This stage is identifying and defining the required data entities for the enterprise to support business functions.

Application Architecture: This stage is identifying and defining the applications needed in data management and support of enterprise business functions.

Architectural Technology: This stage is identifying and defining principles in enterprise technology needed to manage the data so that business functions run properly.

Phase V phase implementation plan has a goal formulate and provide advice on the implementation plan based on an architecture that has been made.

Phase VI conclusions and recommendations in the final part of the research phase. The conclusion contains 
answers to the problems that exist in this research discussion material. Suggestions and advice from researchers who refer to the discussion material. This should be stated clearly and have great possibilities to be implemented.

\section{RESULTS AND DISCUSSION}

Library is an organization whose organizational structure with staff and positions in accordance with their respective duties. A library is required to have the leadership and responsibility for the functioning of the library well. Department of Libraries and Archives Salatiga has a structure which consists of heads of agencies, functional groups, sub-section administration, section libraries, archives section area, library, and section archives.

Department of Libraries and Archives Salatiga has several areas of work in managing information, among others: The Procurement Department, Division of Management, Field Service. Field service in Department of Libraries and Archives divided into two parts, namely: a. Technical Service. Technical Services is a system that is in a library that has a function to set up a library of materials that can be accessed by a Librarian. b. Reader Service. This service is a service that has a direct relationship with a librarian. These services include: service reference, read on-site service, circulation, and other services. Department of Libraries and Archives Salatiga serve readers every day with service time Monday to Friday at 8:00 to 20:00, Saturday and Sunday at 08:00 to 16:00. In detail, the researchers observed the Service Division at the Department of Library and Archives Salatiga. As was explained earlier that the Field Service itself has divided into two parts of the Service. Here, researchers will further explain the relevant reader service. The reader service can serve multiple services include: 1) Member Services, 2) Circulation Service. During the observation process in Department of Libraries and Archives Services section, researchers found there are some obstacles that hinder the organization's business processes, among others: the problem of Internet network, the lack of data security (no operator to monitor CCTV in Department of Libraries and Archives, a detector at the entrance and exit is not working anymore so cannot minimize the loss of books and others.) The lack of human resources services new member registration sections, borrowing, and returning books librarians cause distress. Researchers also found that there is still a lack of use of information system. It is desirable to use information system that can be used to the fullest so that the organization can achieve the purpose, vision, and mission of the organization. But sometimes an organization that seeks to build on the organization's information system without proper planning in the development process and its implementation will run into trouble. Thus, good planning is needed to integrate applications across organizational units. Because of these problems, this research enterprise architecture planning at the Department of Library and Archives of Salatiga in order to improve service to internal and external parties (members of the library, and the entire community in Salatiga).

In this study using Enterprise Architecture Planning (EAP) is one of the few enterprise architecture methodologies based on the Zachman Framework. EAP also is a method or stage in building an information architecture. Generally, EAP is a method of data quality planning approach oriented to business needs and how the implementation of the architecture is done in such a way in an attempt to conduct business turnaround and achieving the mission and organization of information system. EAP is not the business of designing and architecture, but rather make the definition of business requirements and architecture alone. EAP will provide an overview of the blueprint for the information technology, namely data architecture, application architecture, technology architecture, implementation plan to guide the needs of information systems in Department of Libraries and Archives. The strategic plan should support the achievement of the vision, mission, goals and aligned with the business strategy of the Department of Library and Archival Salatiga.

Department of Libraries and Archives Salatiga have multiple applications that are used, among other things: Senayan Library Management System (Slims) is a software library management system (library management system) open-source licensed under GPL v3. Applications used optimally in the Service is Slims for librarians and OPAC for society.

A. Business Architecture

Designing a business architecture on Enterprise Architecture in the Department of Library and Archives Salatiga has some major activities and also supporting activities that can be seen in the picture analysis of the value chain.

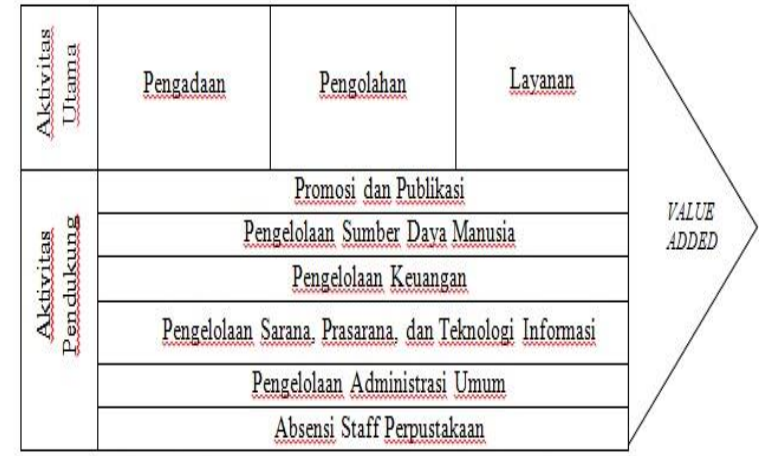

Picture 3. Business Processes at The Department of Libraries and Archives Salatiga

Business Process Library and Archives Office of Salatiga has several stakeholders. Here is a Stakeholders role in the business process the Department of Library and Archives Salatiga:

1. From the Department of Libraries and Archives Salatiga

1) Government Salatiga

2) Department of Libraries and Archives Salatiga

3) School Library in Salatiga integrated 


\section{4) Staff}

2. From the outside the Department of Libraries and Archives Salatiga

1) Library Membership

2) General public

3) Private Agencies Related

The existing business processes in Department of Libraries and Archives has several stakeholders. Here are some stakeholders who have an interest in the key business processes and supporting among others:

Table 1. Stakeholder Relationships with Organizational Activities

\begin{tabular}{|c|c|c|}
\hline $\begin{array}{l}\text { Stakeholder } \\
\text { Aktivitas }\end{array}$ & Dinpersip & Masyarakat \\
\hline $\begin{array}{l}\text { Aktivitas Utama: } \\
\text { - Pengadaan } \\
\text { - Pengolahan } \\
\text { - Layanan }\end{array}$ & $\begin{array}{l}\text {-Pemerintah Kota Salatiga, } \\
\text {-Dinas Perpustakaan dan } \\
\text { Kearsipan Kota Salatiga, } \\
\text {-Staff }\end{array}$ & $\begin{array}{l}\text {-Anggota Perpustakaan, } \\
\text {-Masyarakat Umum Kota } \\
\text { Salatiga, } \\
\text {-Instansi Swasta terkait. }\end{array}$ \\
\hline $\begin{array}{l}\text { Aktivitas Pendukung: } \\
\text {-Pengelolaan SDM } \\
\text {-PengelolaanTeknologi } \\
\text { Informasi } \\
\text {-Pengelolaan Keuangan } \\
\text {-Pengelolaan } \\
\text { Administrasi Umum } \\
\text {-Absensi } \\
\text { Perpustakaan Staff } \\
\end{array}$ & $\begin{array}{l}\text {-Pemerintah Kota Salatiga, } \\
\text {-Dinas Perpustakaan dan } \\
\text { Kearsipan Kota Salatiga, } \\
\text {-Perpustakaan Sekolah di } \\
\text { Salatiga yang terintegrasi } \\
\text {-Staff }\end{array}$ & $\begin{array}{l}\text {-Anggota Perpustakaan, } \\
\text {-Masyarakat Umum Kota } \\
\text { Salatiga, } \\
\text {-Instansi Swasta terkait. }\end{array}$ \\
\hline
\end{tabular}

\section{B. Application Architecture}

Stages of the application architecture are making the definition of an information system used in Department of Libraries and Archives, namely: System Information Retrieval Collection Web-Based, Union Catalog Server (UCS), ISalatiga, Website of Library and Archives Salatiga, Filing System Dynamic, Information System Personal Archive, Ancient Archive Collection, Mapping Department of Libraries and Archives Salatiga, Financial Systems, Systems Officer, Systems Online Cuti, OPAC. Applications is not used effectively, need to be developed to support the organization's business processes.

Table 2. Software at The Department of Libraries and Archives Salatiga

\begin{tabular}{|c|c|c|}
\hline No & $\begin{array}{l}\text { NAMA SI / TI } \\
\end{array}$ & PENGGUNA \\
\hline 1 & $\begin{array}{c}\text { Sistem Penelusuran Informasi Koleksi } \\
\text { Berbasis Web }\end{array}$ & Masyarakat, Admin \\
\hline 2 & Union Catalog Server (UCS) & Masyarakat, Admin \\
\hline 3 & ISalatiga & Masyarakat, Admin \\
\hline 4 & $\begin{array}{c}\text { Website Dinas Perpustakaan dan Kearsipan } \\
\text { Kota Salatiga } \\
\end{array}$ & Masyarakat, Admin \\
\hline 5 & Sistem Kearsipan Dinamis (SKD) & Masyarakat, Admin \\
\hline 6 & Sistem Informasi Arsip Pribadi & Masyarakat, Admin \\
\hline 7 & $\begin{array}{l}\text { Senavan Library Management System } \\
\text { (SLiMS) }\end{array}$ & Pustakawan \\
\hline 8 & Koleksi Arsip Kuno & Masyarakat, Admin \\
\hline 9 & Pemetaan Dinpersip Salatiga & Masyarakat, Admin \\
\hline 10 & Sistem Keuangan & Admin \\
\hline 11 & Sistem Kepegawaian & Admin \\
\hline 12 & Sitem Cuti Online & Admin, Staff \\
\hline 13 & OPAC & Masyarakat \\
\hline
\end{tabular}

C. Technology Architecture

Utilization Technology in Department of Libraries and Archives Salatiga consisting of Hardware and Software.

Table 3. Utilizing Technology at The Department of Libraries and Archives Salatiga

\begin{tabular}{|c|c|c|c|}
\hline Kelompok & Jenis & Jumlah & Pengguna \\
\hline $\begin{array}{l}\text { 1. Hardware } \\
P C\end{array}$ & $\begin{array}{l}\text { Intel Pentum Dual Core G2020 } \\
\text { Intel Core i7-720QM }\end{array}$ & $\begin{array}{l}20 \text { unit } \\
8 \text { unit }\end{array}$ & $\begin{array}{c}\text { Staff, } \\
\text { Pustakawan, } \\
\text { Pengunjung } \\
\text { Staff }\end{array}$ \\
\hline Input Device & Scanner, Mouse, Keyboard & $1,20,20$ unit & $\begin{array}{c}\text { Staff, } \\
\text { Pustakawan, } \\
\text { Pengunjung }\end{array}$ \\
\hline $\begin{array}{l}\text { Output Device } \\
\text { Storage }\end{array}$ & Printer, Monitor & & \\
\hline & Harddisk (500GB) & 20 unit & $\begin{array}{c}\text { Staff, } \\
\text { Pustakawan }\end{array}$ \\
\hline Telephone & $\begin{array}{c}\text { Modem, Mikrotik, HUB, Wiff Access } \\
\text { Point }\end{array}$ & $\begin{array}{c}1,1,1,2 \text { unit } \\
3 \text { unit }\end{array}$ & $\begin{array}{c}\text { Staff, } \\
\text { Pustakawan, } \\
\text { Pengunjung } \\
\text { Staff, } \\
\text { Pustakawan }\end{array}$ \\
\hline $\begin{array}{l}\text { 2. Softuare } \\
\text { Operating } \\
\text { System }\end{array}$ & Dk. Windows 7 & 20 unit & $\begin{array}{l}\text { Staff, } \\
\text { Pustakawan, }\end{array}$ \\
\hline Word & Dts. Word 2010 & 20 unit & $\begin{array}{l}\text { Staff, } \\
\text { Pustakawan, } \\
\text { Penguniung }\end{array}$ \\
\hline $\begin{array}{l}\text { Operation } \\
\text { Spread Sheet }\end{array}$ & DSE. Excel 2010 & 20 unit & $\begin{array}{c}\text { Staff, } \\
\text { Pustakawan }\end{array}$ \\
\hline $\begin{array}{l}\text { Design Grafis, } \\
\text { Security Card }\end{array}$ & $\begin{array}{c}\text { 1k. Visio, Adobe Photoshop } 7 \\
\text { Avast }\end{array}$ & $\begin{array}{l}5 \text { unit } \\
0 \text { unit }\end{array}$ & $\begin{array}{l}\text { Staff, } \\
\text { Pustakawan } \\
\text { Staff }\end{array}$ \\
\hline
\end{tabular}

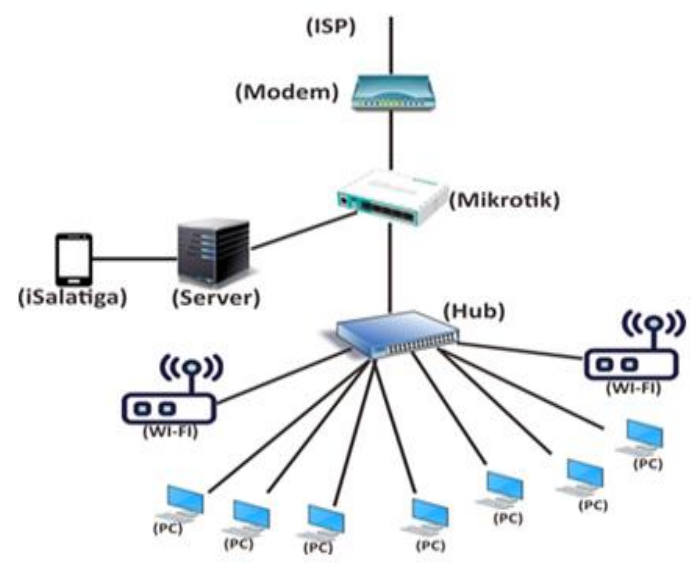

Picture 4. Network Models

In picture 4 there is a picture of the computer network owned by Department of Libraries and Archives. Network Topology Star topology is used. ISP connecting a network of Fiber Optic cable to the modem. Modem connected to Mikrotik that serves as a router and bandwidth management. The proxy connects Server and Hub. The hub is connected to all the computers that are in the scope of the Department of Libraries and Archives Salatiga. Hub distributes internet connection and then forwarded using the hotspot network / Wi-Fi. In addition, the server is also connected with the application Slims and ISalatiga.

D. Gap Analysis

Table 4 is an overview as well as the gap analysis contained in the Department of Library and Archives Salatiga. In the picture below can be seen by three (3) components, applications, infrastructure, and human resources.

Table 4. Information System Gap Analysis at Department of Library and Archives Salatiga 


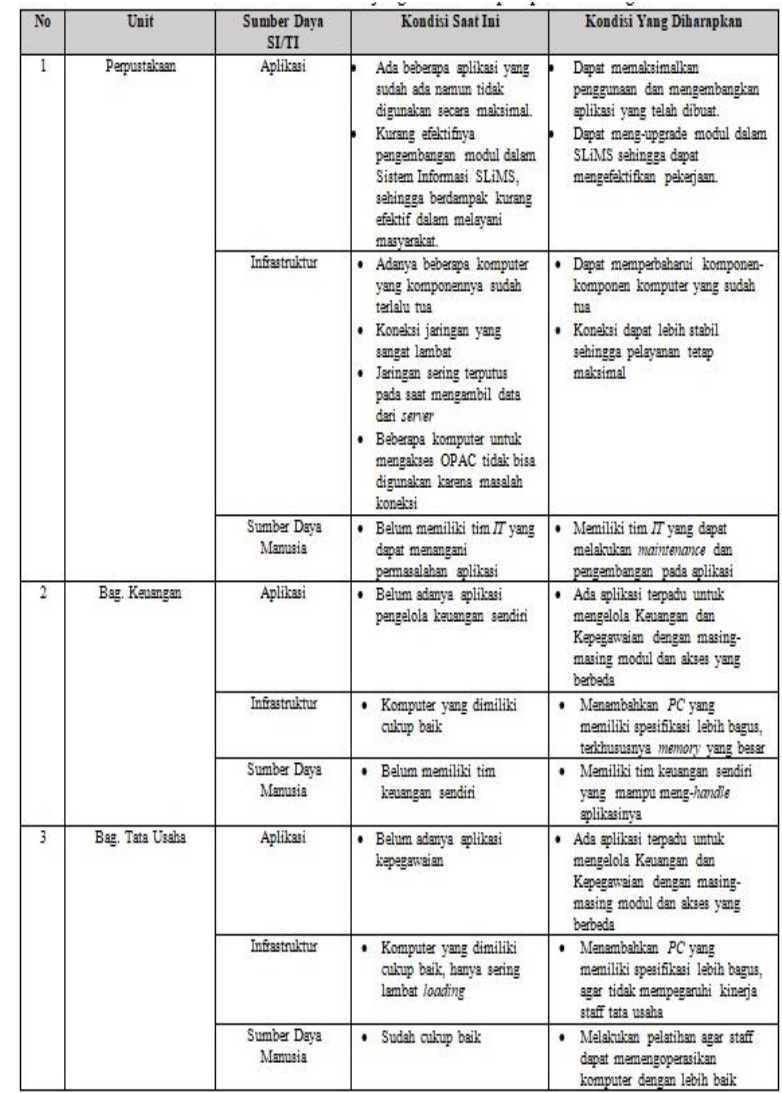

E. Implementation Plan

Plans are offered a 5-year long-term plan. It cannot be too long as technology continues to evolve. The following stages of planning the implementation timescales proposed in Table 5.

Table 5. Information System Implementation Plan

\begin{tabular}{|l|l|l|l|l|l|l|}
\hline No & $\begin{array}{c}\text { Rencana yang } \\
\text { dilimplementasi }\end{array}$ & 2019 & 2020 & 2021 & 2022 & 2023 \\
\hline 1 & $\begin{array}{l}\text { Upgrade dan } \\
\text { Maintenance Jaringan }\end{array}$ & & & & & \\
\hline 2 & Upgrade Harawuare & & & & & \\
\hline 3 & Training SDM & & & & & \\
\hline 4 & Pengembangan SLiMS & & & & & \\
\hline 5 & Aplikasi Keuangan & & & & & \\
\hline
\end{tabular}

\section{CONCLUSION}

Based on the analysis and discussion of recommended some plans for implementation, namely: Upgrade and Maintenance Network, slims Development, Human Resource Training, Hardware Upgrades, Financial Applications. Due to information technology continues to evolve it is only recommended to be developed for 5 years.

\section{ACKNOWLEDGMENT}

Suggestions should be done further research is more leverage in exploring the data and the constraints faced and methods that can design and architecture business that research results can be useful for developing the use of the information system at the Department of Library and Archival Salatiga.

\section{REFERENCES}

AlFatta, H. (2009). Analisis dan Perancangan Sistem Informasi untuk Keunggulan Bersaing Perusahaan dan Organisasi Modern. Yogyakarta: Penerbit Andi.

Bastari, J. (2013). Pemanfaatan Enterprise Architecture Planning pada Akper Harum Jakarta. Jurnal Pilar Nusa Mandiri. 9(2). 153-164. https://doi.org/10.33480/pilar.v9i2.139.

Kustiyahningsih, Y. (2011). Pemrograman Basis Data Berbasis Web Menggunakan PHP \& MySQL. Graha Ilmu, Jakarta.

Robo et all, 2018. Perencanaan Strategis Sistem Informasi Menggunakan Enterprise Architecture Planning Pada PT. Karya Cipta Buana Sentosa Maumere". 4(1). 41-48.

Spewak \& Steven H, 1992. "Enterprise Architecture Planning (Developing a Blueprint forData,Application and Technology)". Jhon Wiley \& Sons,Inc.

Sugiyono. 2010. Statistika Untuk Penelitian. Bandung: Alfabeta.

Sukmadinata \& Syaodih, N, 2009. Metode Penelitian Pendidikan. Bandung: Remaja Rosdakarya.

Supardi, R. (2016). "Pengembangan Model Arsitektur Enterprise Sistem Informasi Menggunakan EAP pada Perguruan Tinggi (Studi Kasus di Universitas Dehasen Bengkulu). Jurnal Media Infotama. 12(1).

Ward, J \& Peppard, J, 2002. Strategic Planning for Information system. Third Edition. John Wiley \& Son's Ltd. Cranfield, Bedfordshire, UK 